\title{
A review on graduate thesis Eğitim fakültelerinde yapılan researches on internet internet konulu lisansüstü completed in education tez çalışmalarına ilişkin bir faculties inceleme
}

\author{
Mehmet Tahir Karaboğa ${ }^{1}$
}

\begin{abstract}
The aim of this research is to examine graduate level (master and doctorate) thesis that have the subject of internet and completed in education faculties in Turkey between 2006-2016. Theses were reviewed in terms of their distribution according to fields, perspective towards the internet, and methodological features. Document analysis was used as a data collection tool in the study. 124 graduate and doctoral theses on the subject of "internet" constituted the sample of this study. Dissertations were obtained among graduate studies completed in education faculties between 2006-2016 by scanning the Higher Education Council's Thesis Documentation search system. A descriptive analysis approach was used in the analysis of the data.

As a result of the research, it has been determined that most of the studies on the internet subject were produced in educational sciences departments and in psychological counseling branch in the education faculties. In the study, it was seen that quantitative method was applied at a very high rate as a research approach, and qualitative and mixed methods were preferred in a limited manner. It has been found that students were preferred mainly as the sample in these thesis researches rather than educators and parents.
\end{abstract}

1 Yrd. Doç. Dr., Mersin Üniversitesi, Eğitim Fakültesi, Türkçe ve Sosyal Bilimler Eğitimi Bölümü, tahirkaraboga@mersin.edu.tr

\section{Özet}

$\mathrm{Bu}$ araştırmanın amacı, Türkiye'de eğitim fakültelerinde 2006-2016 y1llar1 arasinda lisansüstü (yüksek lisans ve doktora) düzeyde yapilan internet konulu tezler incelenerek, bu çalışmaların alanlara göre dağılımları, internete yönelik bakış açısı, yöntemsel özellikler ve internet kavramı ile birlikte ele alınan konular açısından nasıl bir eğilim gösterdiğini ortaya koymaktır. Çalısmada veri toplama aracı olarak doküman incelemesi ne başvurulmuştur. Yükseköğretim Kurulu Tez Dökümantasyon arama sisteminde eğitim fakülteleri bünyesinde 2006-2016 y1llar1 arasinda tamamlanan "internet" konulu yüksek lisans ve doktora tezleri taranarak elde edilen 124 adet tez, bu çalışmanın örneklemini oluşturmuştur. Verilerin analizinde betimsel analiz yaklaşımı kullanılmıştır. Araştırma sonucunda internet konusunu eğitim fakülteleri bünyesi bünyesinde en çok Eğitim Bilimleri Bölümlerinin ele aldığı, bu bölüm içinde de en çok Rehberlik ve Psikolojik Danışmanlık Ana Bilim Dalının konu üzerine tez ürettiği, çalışmalarda araştırma yaklaşımı açısından çok büyük bir oranlarda nicel yönteme başvurulduğu, nitel ve karma yöntemlerin sinırlı oranda tercih edildiği görülmüştür. Araştırmalarda örneklem olarak daha çok öğrencilerin tercih edildiği, eğitimcilerin ve ebeveynlerin çok daha az çalışıldığ 1 tespit edilmiştir. İncelenen çalışmaların 
Karaboğa, M. T. (2017). Eğitim fakültelerinde yapılan internet konulu lisansüstü tez çalıșmalarına ilișkin bir inceleme. Journal of Human Sciences, 14(4), 4492-4506. doi:10.14687/jhs.v14i4.4977

It has been seen that the internet is emphasized as a technological tool for positive use, while the effects of the internet content and risks and hazards from a critical perspective been studied much less.

Keywords: İnternet; Approaches to internet; Internet and education; Mass communication; Education faculties.

(Extended English abstract is at the end of this document) internete bakış açısı değerlendirildiğinde internetin teknolojik bir araç olarak olumlu kullanım biçimine vurgu yapıldı̆̆ı, eleştirel perspektiften internet içeriklerinin etkileri, riskleri ve tehlikelerinin ise çok daha az çalışıldığ görülmüştür.

Anahtar kelimler: İnternet; İnternete yönelik yaklaşımlar; İnternet ve eğitim; Kitle iletişimi; Eğitim fakülteleri.

\section{GİRİŞ}

Günümüzde internet yaşamın her alanına girmiş, özellikle de önemli bir eğitim kaynağı haline gelmiş durumdadır. İnternet içerikleri bireylerin bilgi, duygu, düşünce, inanç ve tutumlarını etkileyen bir güce sahiptir. Eğitim sisteminin süreçlerini doğrudan ya da dolaylı etkileyen bir güç olarak internet içerikleri, aynı zamanda bireylerin kültürünü, dünyayı görme biçimlerini, davranışlarını, karakterlerini de etkileyebilen önemli bir eğitim aracı olarak da karşımıza çıkmaktadır.

Bilimsel araştırmaların öncü kurumları olarak üniversitelerde pek çok fakültede, internet ile ilgili çalışmalar yapmaktadır. Bu alanların başında eğitim fakülteleri gelmektedir. Eğitim fakülteleri çağımızın en önemli olgularından olan internet teknolojisinin farklı boyutları üzerinde araştırmalar yürütmektedir. Eğitim fakülteleri bünyesinde internetin içerikleri, özellikleri, kullanım amaçları, internetin eğitim sistemi üzerinde, öğrenciler üzerinde, öğrencilerin okul başarıları üzerindeki yansımaları, internetin eğitim amaçlı kullanılması vb. konularda lisansüstü düzeyinde de araştırmalar yapilmaktadır.

Bir kitle iletişim aracı olarak internet, günümüzde okullarla rekabet eden yeni nesilleri eğiten önemli bir eğitim kaynağı haline gelmiş durumdadır. Okul kurumlarıyla karşılaştırıldığında çok farklı avantajlara sahip olan internet, neredeyse eğitim kurumlarının işlevlerinin önemli bir kısmını üzerine almış görünmektedir. Özellikle çocuklar ve gençlerin interneti kullanma süreleri oldukça artmış, gündelik hayatın her saatinde zamanlarının büyük bir bölümünü internette oyun oynayarak ya da sosyal medya girerek geçirdikleri gerçeği ile karşı karşıyayız. İnternet içerikleri ve mesajların niteliği, eğitim kurumlarının da temel kitlesini oluşturan bu kesimlerin zihinsel ve ruhsal gelişimleri açısından önemli hale gelmektedir. Birçok insan başta gençler ve çocuklar her gün milyonlarca internet içeriği ve mesajlarının sağanağı altında zamanlarını geçirmektedir. Bu bağlamda eğitim süreçleri ile ilgili yaşanan sorunların anlaşılması, daha nitelikli eğitim hedeflerinin yakalanması açısından eğitim fakültelerinin internet olgusuna yaklaşımları ve bu kapsamda yapılan çalışmaların özellikleri önemli hale gelmektedir.

\section{İnternete yönelik yaklaşımlar}

Sosyal teoride internete yönelik iki ana yaklaşımdan bahsetmek mümkündür. Bunlardan ilki interneti enformasyon (bilgi) toplumu perspektifinden açıklamaya çalışan yaklaşım iken, diğeri ise eleştirel yaklaşımdır. Bilgi toplumu yaklaşımı, internetin bir teknolojik araç olarak imkan ve faydalanma boyutunu ön plana çıkartırken, eleştirel yaklaşım ise internet teknolojisinin üreten, kontrol eden ülkeler üzerinden, daha çok ticari, ekonomik ve kültürel sömürü boyutuna vurgu yapmaktadır. 
Karaboğa, M. T. (2017). Eğitim fakültelerinde yapılan internet konulu lisansüstü tez çalışmalarına ilișkin bir inceleme. Journal of Human Sciences, 14(4), 4492-4506. doi:10.14687/ihs.v14i4.4977

Bilgi toplumu söylemi, iletişim teknolojilerinin toplumsal değişim, dönüşüm, yenilik, kalkınma, yaşam boyu öğrenme, yeniden yapılanma gibi konulardaki rolüne vurgu yapar. Bu söylemler yaşadığımız çağın bir değişim çağı olduğu, bu değişimin önünde durmanın imkânsız olduğu dolaysıyla yeniçağa uyum sağlamak gerektiğini vurgulamaktadır. Bilgi toplumu söylemleri savunucularına göre, bilgisayar teknolojisi sayesinde bilgi dünya çapında hareketlilik kazanmış ve bilgiye ulaşmada büyük kolaylıklar sağlamıştır. Bilgi toplumunda bilgisayar ve internet teknolojileri bilgiye ulaşmada kolaylıklar, fırsatlar ve avantajlar sağlamıştır. Bu çağı temsil eden iletişim teknolojileri toplumsal yaşamın pek çok alanında ekonomik refahı, etkileşimi, kaynaşmayı, bütünleşmeyi, demokratikleşmeyi beraberinde getirmiştir (Bell, 2013; Castels, 2007; Kumar, 1999; McLuhan ve Powers, 2001).

Bilgi toplumu kuramına göre, iletişim teknolojileri eğitim alanı üzerinde de büyük değişim ve dönüşümleri beraberinde getirmektedir. Bu kurama göre, eğitimde bilgi teknolojilerinin ön plana çıkmasıyla beraber ülkeler arasında, kurumlar arasında eğitimcilerin ve öğrencilerin değişimine yönelik programlar ön plana çıkmıştır. Bilgi toplumunda eğitim, yaratıcı düşünen, problem çözme becerisi yüksek, araştıran, eleştiri yapan bir birey ortaya çıkarmıştır. Bilgi çağının, öğrenmeyi herkes için olanaklı kıldığı, yeni eğitim teknolojilerinin gelişmesine yol açtı̆̆ ileri sürülmektedir.

Küresel çağda bilgi toplumuyla birlikte eğitim ve öğretim süreçlerinde değişim yaşanacağı, eğitim programlarının, okulların, öğretmenlerin, okul yöneticilerinin, öğrencilerin rolleri ve işlevlerinin yeniden tartışılacağını vurgulamaktadır (Balay, 2004; Numanoğlu, 1999; Özden, 2002, Tezcan, 1992, Öğüt, 2003). Öğüt (2003), enformatik yüzyıl ya da bilgi çağında, bilginin üretim için temel kaynak olduğu, bilgi üretimi ve iletiminin yaygınlaştığı, bilgi üretimi ve dağıtımında çalışanların çoğunlukta olduğu, sürekli öğrenme ve bilgilenme yoluyla değişme ve gelişmenin kaçınılmaz hale geldiği yeni bir toplumsal ve ekonomik örgütlenme dönemine işaret eder.

Egemen bilgi toplumu kuramı yaklaşımına göre, internet teknolojisi eğitim sistemi ve yapıs1 üzerinde değişimleri meydana getirecek ve dönüştürecektir. Bozkurt bu dönemi şu sözlerle betimlemektedir: "Formel okul sınırlamaları enformasyon toplumunda ortadan kalkacaktır. Şimdiki kapalı eğitim sistemleri yerlerini bilgi ağlarına bırakacaktır. Bu durum gelişmiş bölgeler ile gelişmemiş bölgeler arasındaki boşluğu ortadan kaldıracaktır. Kendi kendine öğrenme eğitimin ana şekli olacaktır. Formel eğitim sisteminde öğrenci öğretmen tarafindan tek taraflı olarak öğretilmektedir. Enformasyon toplumunda öğretmen, özellikle bilgisayar desteği sayesinde bir danışman işlevi görecektir" (Bozkurt, 2006, s. 216).

Bilgi toplumu kuramından farklı olarak eleştirel yaklaşım ise internetin daha çok, ekonomik ve kültürel boyutunu ön plana çıartırken internetin anlaşılabilmesi için bu teknolojinin içinde ortaya çıktığ1 toplumsal yap1 ve bağlamın incelenmesi gerektiğine vurgu yapar. Yaylagül, egemen yaklaşım çerçevesinde bilgisayar ve internete yönelik araştırmaların çoğunun ya teknolojinin kendisi ya da tüketicilerin bu teknolojileri nasıl kullandıkları sorunuyla ilgilendiğini belirtir. Bilgisayar teknolojilerinin ve internetin, küresel kapitalizmin egemen iktidar ilişkileri çerçevesinde geliştirildiği ve dünya sisteminin egemen üretim ve bağımlılık ilişkilerinin üretiminde önemli bir rolü olduğunu belirten Yaylagül'e göre (2013a) bu teknolojiler çokuluslu küresel şirketlerin ihtiyaçları ve çıkarları doğrultusunda üretim ve dağıtımın gerçekleştiği yeni iletişim ortamlarıdır. Bilgisayar ve internet temelde küreselleşme olarak adlandırılan yeni bir sermaye birikim düzeninin bilgi altyapısını oluşturmaktadır.

Yaylagül (2013b) teknoloji ve onun dolayımı ile gerçekleşen iletişimin anlaşılabilmesi için kapitalist üretimin, dağıtımın ve kurumsal yapının doğasının incelenmesi gerektiğini belirtir.

Eleştirel yaklaşıma göre, günümüzde bilgisayar teknolojisinde ve enformasyon alanında bir patlama yaşanmaktadır. Ancak bu gelişmeler kapitalist dünya sisteminin mevcut yapısı ve kâr arayışı altında gerçekleşmektedir. Teknolojilerin ve enformasyonun üretimi, dağıtımı ve tüketimi, kapitalist üretim ve bölüşüm ilişkilerine göre yapılmaktadır. Bilgisayar ve yeni iletişim teknolojilerinin donanım ve içerikleri, kapitalist mülkiyet ilişkileri çerçevesinde gerçekleşmektedir. Eleştirel yaklaşımın savunucularından Hamelink (1991), küreselleşme süreciyle de ulus aşırı kitle iletişim holdinglerinin bütün dünyadaki iletişim içeriklerinin üretim, dağıtım ve tüketim süreçlerini kontrol etmeye 
Karaboğa, M. T. (2017). Eğitim fakültelerinde yapılan internet konulu lisansüstü tez çalıșmalarına ilișkin bir inceleme. Journal of Human Sciences, 14(4), 4492-4506. doi:10.14687/jhs.v14i4.4977

başladığını ifade etmektedir. Hamelink’e göre, dijital teknolojiler otomasyonu hızlandırmış, finansal işbirlikleri açısından sınırları ortadan kaldırmış, global haberlerin ve eğlencenin yeni izleyicilere taşınmasını sağlamıştır. Hamelink dijital teknolojilerin insanoğluna pek çok kolaylık ve erişebilirlik anlamında olanaklar tanımakla birlikte çeşitli tehlikeleri de beraberinde getirdiğini belirtmektedir (Hamelink, 1997)

Eleştirel yaklaşımın diğer bir öncüsü Schiller (1993), iletişim teknolojileri ve kurumlarının küresel boyutta Amerikan emperyalizminin yayılmasına hizmet ettiğini, iletişim ve medya alanındaki kültürel içeriklerin, emperyalist sistemin önemli bir parçası olduğunu, kültürel alanın kapitalist sistemde bir endüstri olarak örgütlendiğini belirtmektedir. Bu sistemde üretilen ürünlerin diğer ürünlerden farklı olarak ideolojik bir karakter taşıdığını ve sistemin çıkarına hizmet ettiğini kitle iletişim araçlarının reklamlarını yaptığı malları satarak tüketime dayalı bir kültürü teşvik ettiğini söylemektedir.

Schiller, bilgisayar ve telekomünikasyon altyapısı olmadan büyük şirketlerin günlük ve küresel işlerini yürütemeyeceklerini, enformasyonun değerli ve satılabilir bir mala dönüştürüldüğünü ifade eder. Schillere göre, küresel şirketlerin yeni enformasyona ve bunların üretimi için kullanılan teknolojilere olan bağımlılı̆̆ artmıs, enformasyonun ticarileşmesi sonucunda yeni enformasyon teknolojileri küresel kapitalizmin motoru olmuştur. Örneğin, bankacılık, turizm, iletişim, ticaret, sigorta, ulaştırma gibi sektörlerde bilginin işlenmesi gerekliliği çok büyüktür (Schiller,1991).

Eleştirel yaklaşıma göre, internet, kitle iletişimi olgusunu gerçekleştiren teknolojik bir araç olarak kapitalist sistemde mülkiyet ilişkilerine ve meta üretimine dayalı örgütlü, ekonomik, politik bir yap1 olarak, kültürel ve ekonomik malların alım satım ilişkilerinin gerçekleştirildiği bir alandır. Burada küresel firmaların sermayelerini geliştirmek ve kârlarını artırmak için ürün ve hizmetlerin pazarlamasında internetin en çok kullanılan mecra olduğu ifade edilmektedir.

Eleştirel yaklaşımın diğer bir savunucusu olan Wade, iletişim ve enformasyon olgusuna daha genel ve bütünsel bir perspektiften bakarak bu alanın kapitalist pazar sisteminin bir parçası olduğunu, bu yapının arkasında Microsoft, Hewlett Packard, Siemens, Alcatel gibi küresel şirketlerin bulunduğunu belirtir. Wade’ye göre, “AOL-Time Warner gibi küresel şirketler Netscape gibi şirketlerle internette önde gelen servis sağlayıcılarıdır. Microsoft Google, Yahoo gibi yazılım şirketleri ve arama motorları da küresel şirketlerin parçalarıdır. Bilgisayar teknolojileri ve internetin amacı, üçüncü dünya ülkelerini küresel pazarın bir parçası haline getirerek bağımlı konumda tutmaktır" (Wade, 2002, s.453).

Underwood, küresel kapitalist sistemde ekonomik ve siyasi güçlerin, bilgiyi paylaşmaktan ziyade satış veya denetim aracı olarak kullandığını, insanların çoğunun bu alandaki bilginin üreticisi değil, pasif alıcısı, tüketicisi konumunda olduğunu, internet ortamına hangi bilgilerin konacağına küresel şirketler ve siyasal iktidarların karar verdiğini belirtmektedir. Underwood'a göre (2002) internet, kullanıcılara sınırsız bir seçenek sunmamakta, enformasyon küresel şirketler tarafindan merkezileştirilmekte, düzenlenmekte ve yönetilmektedir.

\section{İnternet ve eğitim}

Eğitim kurumları, bir toplumda bireylerin dünyayı anlamlandırma ve görme biçimlerinin oluşmasında etkili olan ana unsurlardan birisidir. Bireylerin dünya görüşlerinin şekillenmesinde, düşünce ve fikirlerinin oluşmasında inanç, tutum ve davranışların meydana gelmesinde eğitim kurumları önemli bir rol oynar. Diğer yandan kitle iletişim araçları, çağımızda gösterdiği gelişmelerle birlikte, eğitim kurumlarının bu işlevleriyle rekabet edebilecek bir güce de sahip olmaktadır.

Gündelik hayatın içinde yoğun olarak kullanılan internet, her yaştan insanların en çok başvurduğu bilgi, eğitim ve eğlence kaynaklarının başında gelmektedir. Yapılan araştırmalar, insanların interneti kullanmak için temel gerekçelerini sunmaktadırlar. Buna göre insanlar eğlence, iletişim, sosyalleşme, boş zaman değerlendirme, dinlenme, bilgi alma, olaylar hakkında haberdar olma gibi nedenlerle interneti kullanmaktadır. Türkiye İstatistik Kurumu (TÜİK), 2015 yll 'Hane Halkı Bilişim Teknolojileri Kullanım Araştırması" raporunda Türkiye genelinde internet erişim imkânına sahip hanelerin oranının 2015 yılı Nisan ayında \% 69,5 oranında olduğunu bildirmiştir. 
Karaboğa, M. T. (2017). Eğitim fakültelerinde yapılan internet konulu lisansüstü tez çalıșmalarına ilișkin bir inceleme. Journal of Human Sciences, 14(4), 4492-4506. doi:10.14687/jhs.v14i4.4977

İnternet kullanım amaçları dikkate alındığında, 2015 yılının ilk üç ayında internet kullanan bireylerin \%80,9’u sosyal medya üzerinde profil oluşturma, mesaj gönderme veya fotoğraf vb. içerikleri paylaşırken, bunu \% 70,2 ile online haber, gazete ya da dergi okuma, \% 66,3 ile sağlıkla ilgili bilgi arama, \% 62,1 ile kendi oluşturduğu metin, görüntü, fotoğraf, video, müzik vb. içerikleri herhangi bir web sitesine paylaşmak üzere yükleme, \%59,4 ile mal ve hizmetler hakkında bilgi aramanın takip ettiği ifade edilmiştir (TÜíK, 2015).

İnternetin kullanımı ve amaçlarına ilişkin pek çok çalışma yapılmaktadır. Bu çalışmalar belirli perspektiflerden hareket etmektedirler. Eğitim ile ilişkisi bağlamında internetin kullanımına yönelik olumlu yaklaşım sergileyen bakış açıları, internetin bir imkan ve araç olarak eğitim süreçlerinde kullanılmasına vurgu yapmaktadır. Bu yaklaşımlarda internet, öğrencilerin öğrenme alışkanlıklarını ve deneyimlerini zenginleştirdiği, bireylere bilgileri karşılıklı paylaşma ortamı yarattığı ve diğer kullanıcılar ile fikirlerini tartışma olanağı sunduğu ifade edilmektedir.

Özen, Gülaçtı ve Çıkılı’ya göre (2004) dünyadaki çağdaş uzaktan eğitim uygulamalarında, bilgisayarlar ve internetten yararlanma oldukça önemli bir rol oynamaya başlamış ve geniş bir uygulama alanı bulmuştur. Yazarlar bu alanları kısaca yönetim, öğrenci, masa üstü ve elektronik yayıncılık, materyallerin elektronik dağılımı, iletişim ve bilgisayarlara dayalı öğrenme olmak üzere altı grupta ele almıştır.

Altıntaş ve Kaya, eğitim sürecinde bilgisayarların ve internetin kullanılmaya başlanmasının bilginin nitelik ve niceliğinde büyük bir değişimi beraberinde getirdiğini, akademik çalışmalarda ihtiyaç duyulan her türlü bilgiye ekonomik ve kısa yoldan ulaşılabilme imkânı sunduğunu, bilgiyi başkalarıyla paylaşma imkânı sunduğunu, bilimsel araştırmalara büyük bir veri kaynağı oluşturduğunu ifade etmektedirler (Altıntaş ve Kaya, 2011).

Eleştirel yaklaşımlar ise internetin eğitim süreçlerinde kullanılmasından ziyade, söylenenlerin aksine internet teknolojisini kimlerin kontrol ettiğine, internet içerikleri, internet teknolojisinin ticari, ekonomik ve kültürel sömürü boyutuna vurgu yapmaktadır.

Eleştirel yaklaşımlara göre, günümüzde internet içerikleri çocukları ve gençleri şekillendiren en önemli kaynaklardan biridir. Çocukların ve gençlerin karakterini, kimliklerini, davranışlarını, duygularını, düşüncelerini etkileyen ve şekillendiren bu kaynak, hedef kitleye bir eğitim paketi sunar. Çocuklar bu içeriklerden tüketici yaşam tarzını, modayı, ürün satın almayı, neden satın almaları gerektiğini öğrenirler. Internet içerikleri çocukların iletişim ve ilişki biçimlerini değiştirip dönüştürmekte onlara yanlış bilinç ve çıkarcı fikirler aşılamayabilmekte, şiddet ve cinsiyetçi eğilimler taşıyan kimlikler öğretebilmektedir.

İnternet içeriklerinin başında reklamlar, haberler, filmler, dizi filmler, müzik klipleri, fotoğraflar, oyunlar, facebook, twitter vb. içerikler gelmektedir. Eleştirel yaklaşımlar, internet içeriklerinin, çocukların sosyal olayları, olguları, nesneleri, kişileri, hayatı nasıl anlamlandırmaları konusunda etkide bulunduklarını, bu içeriklerin büyük ölçüde endüstriyel gruplar tarafindan hazırlandığını, yapımlarında büyük paralar harcandığını, yapımında bilimsel alanlardan ve uzmanlardan yararlanıldığını belirtmektedir. Bu programların çocukların ve gençlerin ilgi, ihtiyaç ve sorunları üzerinden kurgulandığı, eğlence formatında tasarlanarak onların duygularını hedeflendiği ifade edilmektedir. Eleştirilerin bir başka noktasını ise, bilgisayar teknolojisi ve internetin, ağırlıklı olarak ABD'de icat edildiği için Amerika'nın egemen değerlerini içerdiği ve yaydığı, Amerika'nın bireyci dünya görüşünü ve bu görüşe dayanan kişiliği yansıttı̆̆ı, bu araçların Amerikan tarzı kitle kültürü değerlerinin yayılmasını sağladığı düşüncesi oluşturmaktadır.

Akçalı, iletişim teknolojilerinin özellikle internetin çocukların ve gençlerin oyun ve eğlence anlayışlarını ve iletişim kurma biçimlerini değiştirdiğini, bu ortamlarda yoğun şiddet, tüketim ve cinsel içerikli mesajlara maruz bırakıldıklarını, bunun da şirketler tarafindan denetlenip yönlendirildiğini belirtmektedir. Akçalı'ya göre, "günümüzde ... çocuk oyunu yarışma konusu haline getirildi. Bugün çocuk kültürünü medya tarafından, şirketler tarafindan denetlenip yönlendiriliyor. Okunacak kitaba, izlenecek filme, tiyatro oyununa, dinlenecek müziğe, şirketler karar veriyor. Çocuk bol çeşit arasında özgürce seçim yaptığını zannediyor" (Akçalı, 2015, s.7). "İnternet üzerinden yayılan şiddet ve cinsellik içeren mesaj ve görüntüler çocuğun zihnini başka 
Karaboğa, M. T. (2017). Eğitim fakültelerinde yapılan internet konulu lisansüstü tez çalışmalarına ilişkin bir inceleme. Journal of Human Sciences, 14(4), 4492-4506. doi:10.14687/ihs.v14i4.4977

hiçbir şeye yer bırakmayacak şekilde doldurmaktadır" (Akçalı, 2015, s.5). "İnternet çocukları kendi kafasındaki görüntülerden uzaklaştırır. Çocuk farkında olmadan cinsel içerikli mesajlar, şiddet ve tüketim konusunda mesajlara maruz kalır ve onları tüketir" (Akçalı, 2015, s. 5).

İnal ise, teknolojinin önemine vurgu yapıldığı post modern çağ olarak nitelendirilen çağda, teknolojinin çocukların toplumsallaşmasını, dünyayı algılama biçimlerini, ilişki biçimlerini ve rollerini olumsuz yönde etkilediğinden bahsetmektedir. İnal'a göre, yeni dönemin postmodern çocuk tipi, yapay zeka, klonlama, robot ve uzay maceraları gibi gerçek ya da hayali temaları, animasyon ve simülasyon gibi tekniklerle öğrenip yeni dünya düzeninin ihtiyaçlarına göre toplumsallaşmaktadır. "Doğanın birtakım simülasyonları ya da yapay gerçekliklerle canlandırıldığı sanal ortamlarda çocuklar, oyun ve oyuncak gibi nesneler ve etkinliklerde piyasanın aktörleri olarak edilgen bir rol içinde büyüyorlar. Çocuklara yaşamın çeşitli ve vehçelerinin hazır paket ürünler halinde sunulduğu böylesi bir ortamda tüketici- çocuk kategorisi, üretim bilgisinin tümüyle dışında yetişiyor; yaratıcıllı̆ı "pastij ve kolaj” olarak görüyor. Bu yetişme sürecinde çocuk için ebeveynler tarafindan her şey okul, giysi, bilgisayar, arkadaşlar, rekreasyon merkezleri, kitaplar vb. sadece seçiliyor ve seçim işi giderek teknik bir konu halini aliyor" (Inal, 2015, s.41).

\section{Araştırmanın amacı ve önemi}

Bu araştırmanın amacı, Türkiye'de eğitim fakültelerinde 2006-2016 y1lları arasında lisansüstü (yüksek lisans ve doktora) düzeyde yapılan internet konulu tezler incelenerek, bu çalışmaların alanlara göre dağılımları, internete yönelik bakış açısı, yöntemsel özellikler ve internet kavramı ile birlikte ele alınan konular açısından nasıl bir eğilim gösterdiğini ortaya koymaktır.

Son ylllarda internet teknolojisi Türkiye'de ve dünyada önemi artan bir konu olmuştur. Günümüz toplumları için "internet toplumu”, "enformasyon toplumu”, "dijital toplum”, "sanayi sonrası post modern toplum" ifadeleri de kullanılmaktadır. İçinde yaşadığımız çağa teknolojik devrimlerin, elektronik, dijital, uydu teknolojilerinin damga vurduğu ifade edilmektedir. Bugün başta öğrenciler olmak üzere milyonlarca insan her gün yoğun bir şekilde internete girmekte ve bu teknolojileri çok farklı amaçlar için kullanmaktadır. Bu teknolojiler eğitim, sosyalleşme, eğlenme, iletişim, oyun oynama, zaman geçirme gibi pek çok farklı amaçlar için kullanılmaktadır. Bugün bir kitle iletişim aracı olarak internet, yeni nesillerin eğitiminde önemli bir yer işgal etmekte ve diğer kitle iletişim araçları ile birlikte eğitimde okullar ile ailelerin konumu ile rekabet eder bir konuma erişmektedir. "Medya klasik eğitim araçlarından (öğretmen, ders kitabı, ansiklopedi vb. ) daha yoğun bir biçimde kullanılmakta, öğrencilerin hayatında önemli rol oynamaktadır. Medya neredeyse çeşitli eğitim kurumlarının işlevlerini üzerine almış görünmektedir” (İnal, 2009, s.14).

$\mathrm{Bu}$ anlamda eğitimin en önde gelen kurumlarından olan eğitim fakültelerinde yapılan tez araştırmalarında internet konusuna hangi açılardan yaklaşıldığı, internetin nasıl ele alındığı, hangi boyutları ile araştırıldığı önemli hale gelmektedir.

\section{YÖNTEM}

\section{Problem}

Türkiye'de eğitim fakültelerinde lisansüstü (yüksek lisans ve doktora) düzeyde 2006-2016 yılları arasında yapılan internet konulu tez çalışmalarının alanlara ve yıllara göre dağılımları, yöntemsel özellikleri, internet olgusuna yaklaşımları açısından nasıl bir eğilim gösterdiklerini belirlemek bu araştırmanın problemini oluşturmaktadır.

\section{Araştırma soruları}

1. Eğitim fakültelerinde lisansüstü düzeyde yapılan internet konulu tez çalışmaları yıllara göre nasıl bir dağ1lım göstermektedir?

2. Eğitim fakültelerinde lisansüstü düzeyde yapılan internet konulu tez çalışmaları eğitim kademesine göre nasıl bir dağılım göstermektedir? 
Karaboğa, M. T. (2017). Eğitim fakültelerinde yapılan internet konulu lisansüstü tez çalıșmalarına ilișkin bir inceleme. Journal of Human Sciences, 14(4), 4492-4506. doi:10.14687/ihs.v14i4.4977

3. Eğitim fakültelerinde lisansüstü düzeyde yapılan internet konulu tez çalışmaları bölümlere göre nasıl bir dağılım göstermektedir?

3.1. Lisansüstü düzeyde yapılan internet konulu tez çalşmaları eğitim bilimleri alanındaki programlara göre nasıl bir dağıllım göstermektedir?

4. Eğitim fakültelerinde lisansüstü düzeyde yapılan internet konulu tez çalısmaları yöntem açısından nasıl bir yaklaşım sergilemektedir?

4.1. Eğitim fakültelerinde lisansüstü düzeyde yapılan internet konulu tez çalışmaları araştırma yaklaşımı açısından nasıl bir görünüm sergilemektedir?

4.2. Eğitim fakültelerinde lisansüstü düzeyde yapılan internet konulu tez çalışmaları veri toplama arac1 açısından nasıl bir görünüm sergilemektedir?

4.3. Eğitim fakültelerinde lisansüstü düzeyde yapılan internet konulu tez çalışmaları örneklem açısından nasıl bir özellik göstermektedir?

5. Eğitim fakültelerinde lisansüstü düzeyde yapılan internet konulu tez çalışmalarında internet olgusuna yönelik nasıl bir yaklaşım sergilenmektedir?

6. Eğitim fakültelerinde lisansüstü düzeyde yapılan internet konulu tez çalışmaları birlikte ele alındıkları konular açısından nasıl bir dağılım göstermektedir?

\section{Örneklem}

$\mathrm{Bu}$ çalışmada amaçlı örneklem kullanılmıştır. Amaçlı örneklem, araştırmanın daha derinlemesine yapılabilmesi için bilgi zengini durumları tercih etmektir. Amaçlı örneklemde, cevapları aranan sorulara 1ş1k tutacak olan bilgi bakımından zengin durumlara odaklanılır. Ölçüt örneklem daha önceden belirlenmiş bazı önemli ölçütleri karşılayan tüm durumları çalışmak ve gözden geçirmek mantığıyla oluşturulmuştur. Seçilmiş olan durumların konuyla ilgili zengin içerik içermesi önemlidir (Patton, 2014). Yükseköğretim Kurulu Tez Dökümantasyon arama sisteminde eğitim fakülteleri bünyesinde 2006-2016 yılları arasında tamamlanan "internet" konulu yüksek lisans ve doktora tezleri taranarak elde edilen 124 adet tez, bu çalışmanın örneklemini oluşturmuştur.

\section{Veri toplama araçları, verilerin toplanması ve analiz}

Çalışmada veri toplama aracı olarak doküman incelemesine başvurulmuştur. Çalışma konusuyla ilgili bilgi içeren yazılı materyallerin analizini kapsayan doküman incelemesi, nitel araştırmalarda etkili bir şekilde kullanılması gereken önemli bir bilgi kaynağıdır (Yıldırım ve Şimşek, 2013). Verilerin toplanması: Yükseköğretim Kurulu Tez Dökümantasyon arama sisteminde eğitim fakülteleri bünyesinde 5 Nisan 2017 ile 10 Mayıs 2017 tarihleri arasında Yükseköğretim Kurulu Tez Dökümantasyon sisteminde yer alan 2006 ile 2016 ylları arasında Eğitim Fakültelerinde yapılan “internet” başlıklı yüksek lisans ve doktora tezler taranarak 137 adet teze ulaşılmıştır. Tezlerden 13 adetine erişime kapalı olduğundan ulaşılamamış ve 124 adet tez bu çalışmanın verilerini oluşturmuştur.

Verilerin analizinde, betimsel analiz yaklaşımı kullanılmıştır. Betimsel analiz, elde edilen verilerin daha önce belirlenen başlıklara göre incelenip yorumlanmasını içeren analiz yöntemidir (Yıldırım ve Şimşek, 2013).

\section{BULGULAR}

Bu bölümde araştırma soruları ışığında Türkiye'de Eğitim Fakültelerinde lisansüstü düzeyde 2006-2016 yılları arasında yapılan internet konulu tez çalışmalarının yıllara, eğitim kademesine, bölümlere, programlara, göre nasıl bir dağılım gösterdiği, bu çalışmaların yöntem, araştırma yaklaşımı, veri toplama aracı, örneklemi ve ele alınan konular açısından nasıl bir görünüm sergiledikleri incelenmeye çalışılmıştır. 
Karaboğa, M. T. (2017). Eğitim fakültelerinde yapılan internet konulu lisansüstü tez çalışmalarına ilişkin bir inceleme. Journal of Human Sciences, 14(4), 4492-4506. doi:10.14687/jhs.v14i4.4977

1. Eğitim fakültelerinde lisansüstü düzeyde yapılan internet konulu tez çalışmaları yıllara göre nasıl bir dağılım göstermektedir?

Tablo 1. Eğitim fakültelerinde lisansüstü düzeyde yapılan internet konulu tez çalısmalarının yıllara göre dağılımı

\begin{tabular}{lcccccccccccc}
\hline Y11 & $\mathbf{2 0 0 6}$ & $\mathbf{2 0 0 7}$ & $\mathbf{2 0 0 8}$ & $\mathbf{2 0 0 9}$ & $\mathbf{2 0 1 0}$ & $\mathbf{2 0 1 1}$ & $\mathbf{2 0 1 2}$ & $\mathbf{2 0 1 3}$ & $\mathbf{2 0 1 4}$ & $\mathbf{2 0 1 5}$ & $\mathbf{2 0 1 6}$ & Toplam \\
\hline $\mathbf{f}$ & 6 & 12 & 8 & 7 & 14 & 10 & 10 & 21 & 14 & 16 & 6 & 124 \\
$\mathbf{0}$ & 5 & 10 & 6,5 & 5.5 & 11 & 8 & 8 & 17 & 11 & 13 & 5 & 100 \\
\hline
\end{tabular}

Türkiye'de Eğitim fakültelerinde lisansüstü düzeyde 2006-2016 y1lları arasında yapılan internet konulu tez çalışmaları yıllara göre dağılımı incelendiğinde inişli çıkışlı bir seyir göze çarpmaktadır. 2006 ile 2009 yılları arasında yapılan çalısma sayısı diğer yıllara göre az olmasına rağmen 2007 yılında konuya ilişkin yapılan çalışma sayısı dikkat çekici şekilde daha fazla olmuştur. 2010 ile 2015 yılları arasında en çok 2013 ile 2015 yılları arasında çalışma sayısı diğer yıllara göre daha fazla olduğu göze çarpmaktadır. 2016 yılında ise çalışma sayısında dikkat çekici bir şekilde düşüş görülmektedir.

2. Eğitim fakültelerinde lisansüstü düzeyde yapılan internet konulu tez çalı̧̧maları eğitim kademesine göre nasıl bir dağılım göstermektedir?

Tablo 2. Eğitim fakültelerinde lisansüstü düzeyde yapılan internet konulu tez çalısmalarının eğitim kademesine göre dağılımı

\begin{tabular}{lll}
\hline Eğitim kademesi & f & $\mathbf{0}$ \\
\hline Yüksek lisans & 105 & 85 \\
Doktora & 19 & 15 \\
Toplam & 124 & 100 \\
\hline
\end{tabular}

İncelenen lisansüstü çalışmalar eğitim kademesine göre incelendiğinde çalışmaların \% 85’inin yüksek lisans tezi, \% 15 'inin ise doktora düzeyindeki tezlerden oluştuğu gözlemlenmiştir. İnternet konusunun eğitim fakültelerinde yüksek lisans aşamasında daha çok çalışıldığı görülmektedir.

3. Eğitim fakültelerinde lisansüstü düzeyde yapılan internet konulu tez çalışmaları bölümlere göre nasıl bir dağılım göstermektedir?

Tablo 3. Eğitim fakültelerinde lisansüstü düzeyde yapılan internet konulu tez çalısmalarının bölümlere göre dağılımı

\begin{tabular}{|c|c|c|c|c|c|c|}
\hline \multirow[t]{2}{*}{ Bölümler } & \multicolumn{2}{|c|}{ Tez sayıs1 } & \multicolumn{2}{|c|}{$\begin{array}{c}\text { Yüksek } \\
\text { Lisans }\end{array}$} & \multicolumn{2}{|c|}{ Doktora } \\
\hline & f & $\%$ & f & $\%$ & f & $\%$ \\
\hline Eğitim Bilimleri Bölümü & 57 & 46 & 50 & 47.5 & 7 & 37 \\
\hline Bilgisayar ve Öğretim Teknolojileri Eğitimi & 33 & 26.5 & 28 & 27 & 5 & 26.5 \\
\hline Matematik ve Fen Bilimleri Eğitimi Bölümü & 8 & 6.5 & 6 & 5.5 & 2 & 10.5 \\
\hline Yabancı Diller Eğitimi Bölümü & 8 & 6.5 & 6 & 5.5 & 2 & 10.5 \\
\hline Temel Eğitimi Bölümü & 8 & 6.5 & 6 & 5.5 & 2 & 10.5 \\
\hline Sosyal Bilimler ve Türkçe Eğitimi Bölümü & 6 & 5 & 6 & 5.5 & 0 & 0 \\
\hline Güzel Sanatlar Eğitimi Bölümü & 2 & 1.5 & 1 & 1 & 1 & 5 \\
\hline Aile Ekonomisi ve Beslenme Öğr. Bölümü & 2 & 1.5 & 2 & 2 & 0 & 0 \\
\hline Toplam & 124 & 100 & 105 & 100 & 19 & 100 \\
\hline
\end{tabular}


Karaboğa, M. T. (2017). Eğitim fakültelerinde yapılan internet konulu lisansüstü tez çalıșmalarına ilișkin bir inceleme. Journal of Human Sciences, 14(4), 4492-4506. doi:10.14687/jhs.v14i4.4977

Tezlerin alanlara göre dağılımı şu şekildedir: Eğitim Bilimleri Bölümü 57, Bilgisayar ve Öğretim Teknolojileri Eğitimi Bölümü 33, Matematik ve Fen Bilimleri Eğitimi Bölümü 8, Sosyal Bilimler ve Türkçe Eğitimi Bölümü 6, Yabanc1 Diller Eğitimi Bölümü 8, Güzel Sanatlar Eğitimi Bölümü. 2, Aile Ekonomisi ve Beslenme Öğretmenliği Bölümü 2, Temel Eğitim Bölümü 8.

\subsection{Lisansüstü düzeyde yapılan internet konulu tez çalışmalan eğitim bilimleri alanındaki programlara göre nasıl bir dağılım göstermektedir?}

Tablo 4. Lisansüstü düzeyde yapılan internet konulu tez çalışmalarının eğitim bilimleri alanındaki programlara göre dağıllımı

\begin{tabular}{|c|c|c|c|c|c|c|}
\hline \multirow[t]{2}{*}{ Eğitim Bilimleri Bölümü } & \multicolumn{2}{|c|}{$\begin{array}{c}\text { Toplam Tez } \\
\text { Sayı1 }\end{array}$} & \multicolumn{2}{|c|}{ Yüksek Lisans } & \multicolumn{2}{|c|}{ Doktora } \\
\hline & f & $\%$ & f & $\%$ & f & $\%$ \\
\hline Eğitim Programları ve Öğretim & 13 & 23 & 10 & 20 & 3 & 43 \\
\hline Eğitim Yönetimi Denetimi ve Planlaması & 17 & 30 & 17 & 34 & 0 & 0 \\
\hline Eğitimde Ölçme ve Değerlendirme & 1 & 1.5 & 1 & 2 & 0 & 0 \\
\hline Rehberlik ve Psikolojik Danışmanlık & 26 & 45.5 & 22 & 44 & 4 & 57 \\
\hline Toplam & 57 & 100 & 50 & 100 & 7 & 100 \\
\hline
\end{tabular}

Eğitim Bilimleri bünyesinde bulunan programlardan sırasıla rehberlik ve psikolojik danışmanlık programlarında \% 45.5 oranında en fazla çalışmanın yapıldığı program olarak göze çarpmaktadır. Ardından eğitim yönetimi denetimi teftişi ve planlaması programlarında \% 30 , eğitim programları ve öğretim programlarında \% 23 oranlarında konuya ilişkin çalışma yürütüldüğü görülmektedir. Ölçme ve değerlendirme programında ise \% 1.5 gibi düşük bir oranda çalışma yürütülmüştür. Yüksek lisans düzeyinde programlar karş̧laştırıldığında rehberlik ve psikolojik danışmanlık programlarında $\% 44$, eğitim yönetimi, denetimi ve planlaması programlarında $\% 34$, eğitim programları ve öğretim programlarında ise \% 20 oranında konuya ilişkin çalışma yürütmüştür. Doktora düzeyinde ise, rehberlik ve psikolojik danışmanlık \% 57 ve eğitim yönetimi ve denetimi $\% 43$ ile ön plana çıkmıştır.

\section{Eğitim fakültelerinde lisansüstü düzeyde yapılan internet konulu tez çalı̧̧maları yöntem açısından nasıl bir yaklaşım sergilemektedir?}

Örneklemde yer alan, eğitim fakültelerinde lisansüstü düzeyde yapılan internet konulu tez çalışmaları hangi yöntemin (nitel, nicel veya karma yöntem) tercih edildiği, çalısmaların veri toplama araçlarının neler olduğu, çalışmaların örneklemlerinin hangi gruplardan seçildiği, örneklemin eğitimci ve öğrenciler açısından nasıl dağıldığı boyutlarında incelenmiştir.

\subsection{Eğitim fakültelerinde lisansüstü düzeyde yapılan internet konulu tez çalışmaları araştırma yaklaşımı açısından nasıl bir görünüm sergilemektedir?}

Tablo 5. Eğitim fakültelerinde lisansüstü düzeyde yapılan internet konulu tez çalışmalarında izlenen araştırma yaklaşımları

\begin{tabular}{lcc}
\hline Araştırma Yaklaşımı & $\mathbf{f}$ & $\mathbf{0}$ \\
\hline Nicel yöntem & 117 & 94 \\
Nitel yöntem & 2 & 2 \\
Hem nitel hem nicel & 5 & 4 \\
\hline Toplam & 124 & 100 \\
\hline
\end{tabular}

Örnekleme giren tez çalışmalarında izlenen araştırma yaklaşımları incelendiğinde \% 94'ünde nicel yöntem tercih edildiği görülmektedir. Araştırmalarda hem nitel hem nicel yöntemlerin bir 
Karaboğa, M. T. (2017). Eğitim fakültelerinde yapılan internet konulu lisansüstü tez çalıșmalarına ilișkin bir inceleme. Journal of Human Sciences, 14(4), 4492-4506. doi:10.14687/jhs.v14i4.4977

arada kullanıldığı çalışmaların oranının \% 5 olduğu, nitel çalışılan tezlerin oranının ise \% 2 gibi çok düşük bir oranda gerçekleştiği görülmektedir.

\subsection{Eğitim fakültelerinde lisansüstü düzeyde yapılan internet konulu tez çalışmaları veri toplama aracı açısından nasıl bir görünüm sergilemektedir?}

Tablo 6. Eğitim fakültelerinde lisansüstü düzeyde yapılan internet konulu tez çalışmalarında kullanılan veri toplama araçları

\begin{tabular}{lcc}
\hline Veri toplama araci & f & $\mathbf{0}$ \\
\hline Anket & 37 & 30 \\
Ölçek & 64 & 52 \\
Test & 9 & 7 \\
Mülakat & 3 & 2.5 \\
Anket ve Ölçek & 4 & 3 \\
Anket ve mülakat & 7 & 5.5 \\
\hline Toplam & 124 & 100 \\
\hline
\end{tabular}

Örneklemde yer alan tez çalışmaları incelendiğinde çalışmalarda veri toplama aracı olarak sırasıyla en çok ölçek (\% 52) ve anketin (\% 30) tercih edildiği görülmektedir. Ölçek ve anketin dışında test ve mülakat gibi araçların da kullanıldığı görülmekte fakat bunların oranlarının ise (test \% 7, mülakat ise \% 2.5) düşük oranlarda kaldığı tespit edilmiştir. Ölçek ve anketin bir arada tercih edildiği çalışmaların oranı $\% 3$, anket ve mülakatın bir arada kullanıldığı çalışmaların oranı ise \% 5.5 oranında olmuştur.

\subsection{Eğitim fakültelerinde lisansüstü düzeyde yapılan internet konulu tez çalışmaları örneklem açısından nasıl bir özellik göstermektedir?}

Tablo 7. Eğitim fakültelerinde lisansüstü düzeyde yapılan internet konulu tez çalışmalarında yer alan örneklem grupları

\begin{tabular}{lcc}
\hline Örneklem gruplar1 & f & $\mathbf{0}$ \\
\hline Lise öğrencileri & 30 & 24 \\
Üniversite öğrencileri & 26 & 21 \\
Ortaokul öğrencileri & 22 & 17.5 \\
İlkokul öğrencileri & 19 & 15.5 \\
Lise öğretmenleri & 6 & 5 \\
Ortaokul ve ilkokul öğrencileri & 5 & 4 \\
İlkokul öğretmen ve öğrenci & 4 & 3 \\
Öğretim görevlileri & 4 & 3 \\
Ortaokul öğretmenleri & 2 & 1.5 \\
Öğretim elemanları ve Üniversite Öğrencileri & 2 & 1.5 \\
İlkokul öğretmenleri & 1 & 1 \\
Ortaokul öğretmen ve öğrencileri & 1 & 1 \\
Lise müdürleri & 1 & 1 \\
Üniversite ve lise öğrencileri & 1 & 1 \\
\hline Toplam & 124 & 100 \\
\hline
\end{tabular}

İncelenen tez çalışmaları örneklem açısından incelediğimizde lise öğrencilerinin \% 24, üniversite öğrencilerinin \% 21, ortaokul öğrencilerinin \% 17.5, ilkokul öğrencilerinin \% 15, oranlarında tercih edildiği görülmüştür. Daha sonra sirasiyla lise öğretmenleri \% 5, ortaokul ve ilkokul öğrencileri \% 4, ilkokul öğretmenleri ve öğrencileri $\% 3$, öğretim elemanları \% 3, ortaokul öğretmenleri \% 1.5, öğretim elemanları ve üniversite öğrencileri $\% 1.5$, ilkokul öğretmenleri \% 1, ortaokul öğretmen ve öğrencileri \% 1 , lise müdürleri \% 1 , üniversite ve lise öğrencileri ise \% 1 gelmektedir. Burada daha çok lise, üniversite, ortaokul ve ilkokul öğrencileri ile oluşturan örneklemlerin tercih edildiği, lise, üniversite, ortaokul, ilkokul öğretmenleri ve farklı kademelerin bir 
Karaboğa, M. T. (2017). Eğitim fakültelerinde yapılan internet konulu lisansüstü tez çalıșmalarına ilișkin bir inceleme. Journal of Human Sciences, 14(4), 4492-4506. doi:10.14687/jhs.v14i4.4977

arda çalışıldığı örneklemlerin daha sınırlı kaldığı görülmektedir. Ayrıca bu örneklem gruplarının dışında ebeveyn gruplarının çalışılmadığı ve tercih edilmediği göze çarpmaktadır.

\subsection{1. İnternet konusuna yönelik eğitim fakültelerinde yapılan lisansüstü çalışmalarda seçilen örneklemler eğitimci ve öğrenci açısından nasıl bir dağılım göstermektedir?}

Tablo 8. İnternet konulu lisansüstü çalışmalarda örneklemlerin eğitimci ve öğrenci açısından dağılımı

\begin{tabular}{lll}
\hline Örneklem grupları & $\mathrm{f}$ & $\%$ \\
\hline Öğrenciler & 106 & 85.5 \\
Ë̆itimciler & 14 & 11 \\
Ögrenci ve eğitimci birlikte & 4 & 3.5 \\
\hline Toplam & 124 & 100 \\
\hline
\end{tabular}

İncelenen lisansüstü tez çalışmalarının örneklemlerini eğitimciler ve öğrenciler açısından sınıflandırdığımızda öğrencilerin \% 85.5 oranında, eğitimcilerin \% 11 oranında, hem eğitimci hem de öğrencilerin birlikte tercih edildiği örneklemlerin ise \% 3.5 oranında olduğu bulunmuştur.

\section{Eğitim fakültelerinde lisansüstü düzeyde yapılan internet konulu tez çalışmalarında internet olgusuna yönelik nasıl bir yaklaşım sergilenmektedir?}

Tablo 9. Eğitim fakültelerinde lisansüstü düzeyde yapılan internet konulu tez çalışmalarında internet olgusuna yönelik yaklaşımlar

\begin{tabular}{lcc}
\hline İnternetin kullanımına yönelik yaklaşım & f & \% \\
\hline İnternet kullanımı olumlanmakta & 62 & 50 \\
İnternetin kulanım biçimi eleştirilmekte & 45 & 37 \\
Ne olumlanmakta ne de eleştirilmekte & 16 & 13 \\
\hline Toplam & 124 & 100 \\
\hline
\end{tabular}

Türkiye'de internet konusuna yönelik eğitim fakültelerinde yapılan lisansüstü çalışmalarda internet kullanımına yönelik yaklaşımları incelediğimizde internet kullanımını olumlu açıdan ele alan çalışmaların oranı $\% 50$, internetin kullanım biçimini eleştiren çalışmaların oranı $\% 37$, ne olumlayan ne de olumsuzlayan yaklaşım sergileyen çalısmaların oranı ise \% 13 olmuştur. İnternet kullanımını olumlayan yaklaşımlar daha çok internetin eğitim amaçlı kullanılmasına "internet tabanlı öğretim", "internetin eğitim amaçlı kullanımı", "internet destekli eğitim", "internet ile uzaktan eğitim" boyutlarında vurgu yapmaktadır. İnternet kullanımını eleştirel bir açıdan ele alan çalısmaların ise konuyu daha çok "internet bağımlılığı" ve "problemli internet kullanımı" kavramları çerçevesinde ele aldıkları görülmüştür.

Bilgisayar ve internet kullanımının eğitim ve öğretimdeki olumsuz etkilerinden olan internetin içerikleri, bu içeriklerin özellikleri, hazırlanışı ve kaynakları, internetin nasıl bir bilgi ve eğitim kaynağı olduğu, internetin eğitim süreçleri üzerindeki etkileri gibi konuların üzerinde pek durulmayan konular olduğu görülmektedir. Yapılan çalışmalarda internetin eğitimle ilişkili olarak ekonomik ve sosyo-kültürel boyutunun ihmal edildiği tespit edilmiştir. 
Karaboğa, M. T. (2017). Eğitim fakültelerinde yapılan internet konulu lisansüstü tez çalışmalarına ilișkin bir inceleme. Journal of Human Sciences, 14(4), 4492-4506. doi:10.14687/jhs.v14i4.4977

Tablo 10. Eğitim fakültelerinde internet ile ilgili yapılan lisansüstü tezlerde ele alınan konular

\begin{tabular}{|c|c|c|}
\hline İnternet kavramının birlikte çalışıldığı konular & $\mathrm{f}$ & $\%$ \\
\hline $\begin{array}{l}\text { - İnternet tabanlı öğretim, eğitim amaçlı kullanımı, internet destekli eğitim, } \\
\text { internet ile uzaktan eğitim }\end{array}$ & 28 & 22.5 \\
\hline - $\quad$ Internet bağımlılığı & 25 & 20 \\
\hline $\begin{array}{l}\text { - Öğretmenlerin, öğrencilerin internet kullanımı, faydalanması, } \\
\text { yararlanması }\end{array}$ & 17 & 13.5 \\
\hline - Problemli internet kullanımı & 15 & 12 \\
\hline - $\quad$ Internetin okul başarısı, öğrenci başarısı, akademik başarıya etkisi & 13 & 10.5 \\
\hline - $\quad$ İnternet kullanım amaçları, nedenleri, alışkanlıkları & 8 & 6.5 \\
\hline - $\quad$ Internetin dil eğitiminde kullanılması & 6 & 5 \\
\hline - $\quad$ Internet kullanım riskleri ve güvenliği & 3 & 2.5 \\
\hline - $\quad$ Internet ve saldirganlik & 2 & 1.5 \\
\hline Diğer & 7 & 6 \\
\hline Toplam & 124 & 100 \\
\hline
\end{tabular}

İnternet konusuna yönelik eğitim fakültelerinde yapılan lisansüstü tezler, internet kavramı ile birlikte çalışılan konular açısından incelendiğinde; internet tabanlı öğretim, eğitim amaçlı kullanımı, internet destekli eğitim, internet ile uzaktan eğitim konularının \% 22.5 oranında, internet bağımlilı̆̆1 konusunun \% 20 oranında, öğretmenlerin, öğrencilerin internet kullanımından faydalanmas1, yararlanmas1 konusunun \% 13.5, problemli internet kullanım1 konusunun \% 12, internetin okul başarısı, öğrenci başarısı, akademik başarıya etkisi konusunun \% 10.5, internet kullanım amaçları ve nedenleri konusunun $\% 6.5$, internetin dil eğitiminde kullanılması konusunun $\% 5$, internet kullanım riskleri ve güvenliği konusunun $\% 2.5$, internet ve saldırganlık konusunun $\% 1.5$, diğer konuların ise \% 6 oranında çalışıldığı görülmüştür. İnternet ile ilgili şu konuların ise çalışılmadığ gözlemlenmiştir: İnternet konusunda ebeveyn ve öğretmenlerin eğitimi, internet ve tüketim, internet ve şiddet, internet ve cinsiyet rolleri, internet kullanımının okul başarısına olumsuz etkileri, güvenli ve sağlıklı internet kullanma eğitimi, internet ve reklamlar, internet ve bilgisayar oyunları, internet ve siber suçlar, facebook, twitter, internettin sosyalleşme ve iletişim biçimleri üzerindeki etkileri.

\section{TARTIŞMA, SONUÇ ve ÖNERİLER}

1. Türkiye'de eğitim fakültelerinin lisansüstü programlarında 2006 ile 2016 yılları arasında tamamlanan internet konulu lisansüstü tezlerin çalışma sayısı açısından inişli çıkışlı bir seyir gösterdiği, bu yıllar içinde konuyla ilgili en fazla 2013 yılında çalısma yapıldığı görülmüştür.

2. Türkiye'de internet konusuna yönelik eğitim fakültelerinde yapılan lisansüstü tezler bölümlere ve programlara göre incelendiğinde Eğitim Bilimlerinin ve Bilgisayar ve Öğretim Teknolojileri Eğitimi alanlarının bu konuya yoğunlukla eğilim gösterdikleri görülmüştür. Eğitim Bilimleri içerisinde de konuya ağırlıklı olarak Rehberlik ve Psikolojik Danışmanlık programlarında yürütülen tezlerde yer verildiği bunu Eğitim Yönetimi Teftişi ve Planlaması programının izlediği belirlenmiştir. Eğitim Fakültelerinde yer alan Matematik ve Fen Bilimleri Eğitimi, Yabancı Diller Eğitimi, Temel Eğitim Bölümü, Sosyal Bilimler ve Türkçe Eğitimi, Güzel Sanatlar Eğitimi, Aile Ekonomisi ve Beslenme Öğretmenliği gibi bölümler yukarda belirtilen iki bölüme göre internet konusunda daha az sayıda çalışma yapmış ve konuya daha az eğilimli olmuştur.

3. İncelenen lisansüstü tezlerde araştırma yaklaşımı açısından ağırlıklı olarak nicel yöntem kullanıldığı görülmüştür. Veri toplama aracı olarak ise en çok ölçek daha sonra anket kullanıldığ1 tespit edilmiştir. İnternet konulu tezlerin örneklemlerinin en çok öğrenci gruplarından (lise, üniversite, ortaokul, ilkokul) öğrencileri gruplarından daha sonra da eğitimciler arasından (öğretmenler ve akademisyenler) seçildiği belirlenmiştir.

4. Üzerinde değerlendirme yapılan lisansüstü tezlerin internet kullanımına yönelik yaklaşımlarına bakıldığında internet kullanımını olumlu açıdan ele alan çalısmaların oranının internetin kullanım biçimini eleştiren çalışmalardan daha yüksek olduğu, ne olumlayan ne de olumsuzlayan yaklaşım 
Karaboğa, M. T. (2017). Eğitim fakültelerinde yapılan internet konulu lisansüstü tez çalışmalarına ilişkin bir inceleme. Journal of Human Sciences, 14(4), 4492-4506. doi:10.14687/jhs.v14i4.4977

sergileyen çalışmaların da söz konusu olduğu görülmüştür. Olumlu yaklaşım sergileyen çalışmalar "internet tabanlı eğitim”, “internetin eğitim amaçlı kullanımı”, "internet destekli eğitim”, "internet ile uzaktan eğitim” gibi kavramlar çerçevesinde konuya yaklaştı̆ğ görülmüştür. İnternet kullanımına yönelik eleştirel yaklaşım benimseyen çalışmalar ise daha çok "internet bağımlılı̆̆ı" ve "problemli internet kullanımı" kavramları üzerinden bir yaklaşım sergilemişlerdir.

Türkiye'de eğitim süreçleri üzerinde önemli bir etken olan internet konusunu eğitim fakülteleri bünyesindeki Eğitim Bilimleri, Bilgisayar ve Öğretim Teknolojileri Eğitimi bölümlerinin en çok ele aldığı görülmüştür. Bunların dışındaki Matematik ve Fen Bilimleri Eğitimi, Yabancı Diller Eğitimi, Temel Eğitim Bölümü, Sosyal Bilimler ve Türkçe Eğitimi, Güzel Sanatlar Eğitimi bölümlerinin de bu konuya daha fazla eğilim göstermeleri ve kendi alanları çerçevesinde çalışmalar yürütmeleri beklenebilir.

Türkiye'de internet konusuna yönelik eğitim fakültelerinde yapılan lisansüstü tezlerin araştırma yaklaşımı açısından çok büyük bir oranda nicel yöntem ile çalışıldığı veri toplama aracı olarak da ölçek ve anket kullanıldığı görülmüştür. Konuyla ilgili bu tercihlerin dışında nitel ve karma yöntemlerin de tercih edilebileceği, mülakat gibi veri toplama araçlarının da derinlemesine bilgi sunacağı, araştırmalara daha farklı bir derinlik ve çeşitlilik katacağı düşünülebilir.

Mevcut çalışmaların internete yönelik bakış açılarında yoğun olarak enformasyon (bilgi) toplumu perspektifinden hareket edilmekte ve internetin teknolojik bir araç olarak kullanımına ve internetin eğitim sisteminin yapısını ve eğitim süreçlerini değiştirmesine ve eğitimin kalitesini artıracağ1 görüşüne vurgu yapıldığ1 görülmektedir. Eğitim fakültelerinde yükseköğrenim düzeyinde internet ile ilgili yapılan çalışmalar internet teknolojisini kontrol eden yapıları, internetin içeriklerinin nelerden oluştuğu, bu içeriklerin nasıl hazırlandığı ve neler hedeflendiği, kamu açısından ne gibi riskler ve tehlikeler barındırdığı konusunda bir eğilim sergilemedikleri görülmektedir. Ayrıca nternet ile ilgili şu konuların da çalışılması önerilebilir: internet konusunda ebeveyn ve öğretmenlerin eğitimi, internet ve tüketim, internet ve şiddet, internet ve cinsiyet rolleri, internet kullanımının okul başarısına olumsuz etkileri, güvenli ve sağliklı internet kullanma eğitimi, internet ve reklamlar, internet ve bilgisayar oyunları, internet ve siber suçlar, facebook, twitter, internettin sosyalleşme ve iletişim biçimleri üzerindeki etkileri.

Eğitim fakültelerinde internet ile ilgili çalışmalarda araştırma örneklemlerini çok yoğun olarak lise, üniversite, ortaokul ve ilkokul öğrencilerinin oluşturduğu, öğretmenler ve akademisyenlerin çok daha az çalışıldığı, ebeveynlerin ise hiç çalışılmadığı görülmüştür. Bu noktada konunun hem internet içerikleri üzerinden hem de eğitim sürecinin diğer paydaşlarından oluşabilecek farklı örneklem grupları üzerinden çalışılması önerilmektedir.

\section{KAYNAKLAR}

Akçalı, S. İ. (2015). Cocuk ve medya. Ankara: Nobel Yayın Dağıtım.

Altuntaş, E., ve Kaya, N., (2001). Psikolojïk danışma ve rehberlik araștırmalarnda biloisayar kullanımı, Ankara: Nobel Yayınları.

Balay, R. (2004). Küreselleşme, bilgi toplumu ve eğitim. Ankara Üniversitesi Eğitim Bilimleri Fakëlltesi Dergisi, 37 (2), 61-82.

Bell, D. (2013). İdeolojinin sonu, ellilerdeki siyasi fikirlerin tükenisine dair. (Çev. V. Hacığlu). Bursa: Sentez yayincilik.

Bozkurt, V. (2006). Endüstriyel ve post-endüstriyel dönüsüm: Bilgi, ekonomi, kültür. Bursa. Ekin Yay1nc1lık.

Castels, M. (2007). Enformasyon çağ̊: ekonomi, toplum ve kültür. (Çev. E. Kılıç). İstanbul: İstanbul Bilgi Üniversitesi Yayınları.

Hamelink, C. J. (1991). Enformasyon devriminden sonra yaşam sürecek mi, Y. Kaplan (Ed.). Enformasyon Devrimi efsanesi içinde (ss. 11-32). İstanbul: Rey Yayınları.

Hamelink, C. J. (1997). New information and communication technologies, social development and cultural $\begin{array}{llll}\text { change. } & 15 & \text { Mays } & 2016\end{array}$ http:/ / citeseerx.ist.psu.edu/viewdoc/download?doi=10.1.1.109.3540\&rep=rep1\&type $=$ pdf adresinden alınmıştur. 
Karaboğa, M. T. (2017). Eğitim fakültelerinde yapılan internet konulu lisansüstü tez çalışmalarına ilişkin bir inceleme. Journal of Human Sciences, 14(4), 4492-4506. doi:10.14687/ihs.v14i4.4977

İnal, K. (2009). Medya okuryazarly̆ğ el kitabı. Ankara, Ütopya yayınevi.

Kumar, K.(1999). Sanayi sonrası toplumdan postmodern topluma çağdas dünyann yeni kuramlar. (Çev. M. Küçük). Ankara: Dost Kitabevi Yayınlan.

McLuhan, M. ve Povers, B.R. (2001). Global kë̈: 21. yü̈ynlda yeryürü yaşaminda ve medyada meydana gelecek dönüsïmler. İstanbul: Scala Yayıncilk.

Numanoğlu, G. (1999). Bilgi toplumu-eğitim-yeni kimlikler-II: Bilgi toplumu ve eğitimde yeni kimlikler. Ankara: Ankara Üniversitesi Eğitim Bilimleri Fakültesi Dergisi. 32 (1-2), 341-350.

Öğüt, A. (2003). Bilgi sağnnda yönetim. (2. Bask1), Ankara: Nobel Yayınc1lk.

Özden, Y. (2002). Ë̆timde dönïsïm: Eğitimde yeni değerler. (4. Baskı), Ankara: Pegem A Yayıncılık.

Özen, Y., Gülaçt, F., Çıkıll, Y. (2004). Eğitim bilimleri ve internet. Doğu Anadolu Bölgesi Araştımalarn Dergisi, 3 (1), 52-57.

Patton, M. Q. (2014). Nitel araştırma ve değerlendirme yöntemleri. (Çev. M. Bütün ve S.B. Demir). Ankara: PegemA Akademi.

Schiller, H. (1993). Zibin yönlendirenler. (Çev. C. Cerit). İstanbul: Pınar Yayınları.

Tezcan, M. (1992). Eğitim sosyolojisi. (8. Baskı). Ankara.

TÜiK, (2015). Hane halkı Bilişim Teknolojileri Kullanım Araştırması. 10 Mayıs 2016 tarihinde http:/ / www.tuik.gov.tr/PreHaberBultenleri.do?id=18660 adresinden alınmıştr.

Underwood, W. (2002). Embracing cyberspace: the evolution of japan's internet culture. 10 Nisan 2017 tarihinde http://williamunderwood.org/uploads/world____cyberspace.pdf adresinden alınmıştır.

Wade, R.(2002). Bridging the digital divide: New route to development or new form of dependency. Global $\begin{array}{lllllll}\text { Governance. } & 8 & \text { (4), } & 443-456 . & 3 & \text { Nisan } & 2017\end{array}$ http://ce.uoregon.edu/aim/InfoSoc05/AltDivide.pdf adresinden alınmıştur.

Yaylagül, L. (2013a). Kitle iletisim kuramlar. Ankara: Dipnot Yayınlan.

Yaylagül, L. (2013b). Bilgisayar ve internetin ekonomi politiği, Global Media Journal, (4), 214-236.

Yıldırım, A. ve Şimşek, H. (2013). Sosyal bilimlerde nitel araştırma yöntemleri. Ankara: Seçkin Yayınlanı.

\section{Extended English Abstract}

\section{Problem}

In recent years, internet technology has become an increasingly important issue in Turkey and in the world. Today, the internet has entered into every aspect of the lives of individuals and has become the most important educational resource especially for children and young people. Internet contents have a power that affects millions of people's' knowledge, emotions, thoughts, beliefs and attitudes. Internet contents have become a force that directly or indirectly affects the educational process. At the same time, internet has becoming one of the most important source of education that affects individuals' cultures, their way of seeing the world, their behaviors, their characters, and their personalities. Education faculties have been conducting conduct researches on the different dimensions of internet technology, which is one of the most important events of our time. In order to understand the problems related to education processes and to achieve the goals of a more qualified education, the studies on internet which were carried out by educational institutions are becoming important.

In this study, thesis studies on internet conducted between 2006-2016 at graduate level (master and doctorate) in the education faculties in Turkey were evaluated. These studies were assessed in terms of their distribution according to years and areas, their methodological characteristics, the topics they were worked with and their attitudes towards the internet phenomenon.

\section{Method}

Document analysis was applied as a data collection technique in the study. Between April 5, 2017 and May 10, 2017, 124 master theses and doctoral theses titled "internet" were searched by the Higher Education Council Thesis Documentation search system. In the analysis of the data, a descriptive analysis approach was followed.

\section{Results}

When the distribution of the number of graduate studies on internet was analyzed according to the years it was found that it was 6 in 2006, 12 in 2007, 8 in 2008, 7 in 2009, 14 in 2010, 10 in 2011, 10 in 2012 and 10 in 201321 in 2014, 14 in 2014, 16 in 2015 and 6 in 2016. 85\% of 124 thesis were master 
Karaboğa, M. T. (2017). Eğitim fakültelerinde yapılan internet konulu lisansüstü tez çalıșmalarına ilișkin bir inceleme. Journal of Human Sciences, 14(4), 4492-4506. doi:10.14687/jhs.v14i4.4977

degree studies and $15 \%$ of them were doctoral studies. In the educational sciences departments, guidance and psychological counseling divisions were ranked as the area which studied the subject at first by $45.5 \%$. This is followed by department of educational administration, supervision and planning with $30 \%$, department of curriculum and instruction with $23 \%$.

When examining graduate studies on internet in education faculties in Turkey, it was founded that $94 \%$ of the studies were quantitative, $4 \%$ were both qualitative and quantitative, and only $2 \%$ were qualitative studies. Scales were used at $52 \%$ and questionnaire were used at $30 \%$ as data collection tools.Some of the studies used different tests $(7 \%)$ and interviews $(2.5 \%)$. Surveys using both questionnaires and interviews as data collection tool were 5.5\%.

When we examined the graduate thesis studies in the education faculties on internet in Turkey in terms of the sample, it was observed that high school students ranked first with $24 \%$, followed by university students with $21 \%$, middle school students with $17.5 \%$ and primary school students with $15 \%$. When we classified the samples of the studies, it was observed that $85.5 \%$ of the studies preferred students, $11 \%$ of them preferred educators, and $3.5 \%$ of them preferred both the educators and the students.

When we analyzed the approaches to internet usage in these studies, we found that the rate of studies that take internet usage in education positively constituted the $50 \%$, studies that criticized usage of the internet was abot 37\% and the rate of studies that showed neither positive nor the negative attitude toward internet was about $13 \%$.

Approaches that perceived the use of internet positively were mostly dealt with the issue within the context of "internet based education", "using internet in education", "internet supported education", "distance education with internet". Studies that have taken a critical view of internet use have been seen to be more in line with the concepts of "internet dependency" and "problematic internet use".

The topics in which the concept of internet is studied with in the graduate theses were also examined. The topics and the were determined as followed: Internet-based education, internet usage purposes and reasons, internet addiction, teachers' and students' use of internet, internet usage risks and security, using internet in language learning, internet and aggression and other subjects.

Departments in which the internet topic is studied and the thesis numbers produced in these departments were determined as follows: 57 in Educational Sciences, 33 in Computer and Teaching Technology, 8 in Mathematics and Science Education, 6 in Social Sciences and Turkish Education, 8 in Foreign Language Education, and 2 in Fine Arts Education, 2 in the Family Economics and Nutrition Teacher Training Department, 8 in the Basic Education Department.

\section{Conclusion}

As a result of the research, it was observed that internet issue was studied in graduate theses mostly in Educational Sciences Departments and mainly in Guidance and Psychological Counseling. A very large proportion of studies has been studied quantitatively and qualitative and mixed methods have been preferred limitedly as research approach. The current studies have emphasized the positive use of the internet as a technological tool in and the effects, risks and threats of internet contents from the critical perspective have been studied much less.

Current studies' point of view is actively driven by the information society perspective in which internet is changing the structure of the education system and the educational processes as a technological tool and increasing the quality of education. Studies in the education faculties at graduate levels show that they do not have a tendency to emphasize the structures that control the internet technology, what constitutes the contents of the internet, how these contents are prepared and what they aim for and what kind of risks and dangers they have in the public sector.

It has been seen that the following dimensions of the internet have not been studied in the researches which have titles of internet in education faculties in Turkey (graduate and doctoral level): Parents and teachers' education on internet, internet and consumption, internet and violence, internet and gender roles, negative effects of internet on school success, safe and healthy internet usage training, internet and advertisement, internet and computer games, internet and cyber crimes, facebook, twitter, the effects of internet on socialization and communication forms. 